5. Gachev, G. (1995). National images of the world: General questions Russian. Bulgarian.Kyrgyz.Georgian.Armenian. M.: Progress, 1995 [in Russian].

6. Zapolskaya, N. N. (2003). «General» Slavic literary language: typology of linguistic reflection. M.: Indrik[in Russian].

7. Lyashevskyy, S. (2002). History of Christianity in the Russian land with I the XI centuries. Moscow: FAIRPRESS [in Russian]. Russian].

8. Maslov, Yu. S. (2005). Bulgarian language. Languages of the World. Slavic languages. M.: Academia[in

9. Mudrak, O. A. (2005). Notes about the language and culture of the danubebulgars.Orientaliaet Classica, VI, Aspects of Comparative Literature. Retrieved from http://starling.rinet.ru/Texts/bulgar.pdf [in Russian].

10. Popova, T.V. (2009). Some questions of the eastern bulgarian vocalism. Investigations on Slavic Dialectology: The Phonetical Aspect of the Study of Slavic Dialects, 14, 92-106 [in Russian].

11. Remneva, M. Phonetic processes of the Slavic period. Thesaurus "Humanitarian Russia". Remnova M.L., Chernets L.V., Markina L.A., Arkhangelskaya A. V, Semenov V. B (Eds). Retrieved fromhttp: //www.philol.msu.ru/ tezaurus/library.php? View $=\mathrm{d} \&$ course $=1 \&$ raz $=1 \&$ pod $=2 \&$ par $=5$ [in Russian].

12. Memories of the great Bulgarian opera singer Nikolay Gyaurov. Retrieved from http://www.obektiv.info/?cat=9\&article=3438[in Bulgarian].

13. Stefanov, Tinterov Art. (n.d.). The name of the distinguished Bulgarian artist Boris Hristov.Retrieved fromhttp://borischristoff.net/pdf/olga.pdf [in Bulgarian].

14. Kholopova, (2006). V. Neoevropocentrism: Musical Culture at the turn of the V. Kholopova, L. Canaris, E. Markova, S. Taranets (Eds). Millennium, 1, Odessa: Astroprint[in Russian].

15. Florya, B. N. Legend of the beginning of Slavic writing. Library of YakovKrotov.Retrieved fromhttp://www.krotov.info/history/09/3/flor_00.htm [in Russian].

Стаття надійшла до редакиії 30.01.2019 p.

УДК 78. 03

Татарнікова Анжеліка Анатоліївна, кандидат педагогічних наук, викладач кафедри хорового диригування Одеської національної музичної академії iм. А. В. Нежданової

ORCID 0000-0002-6310-827

angelikatatarnikova75@gmail.com

\title{
«GLORIA» Ф. ПУЛЕНКА В КОНТЕКСТІ ТРАДИЦЙ ХРИСТИЯНСЬКОГО СЛАВОСЛІВ'Я: ОБРАЗНО-СМИСЛОВІ І ЖАНРОВО-СТИЛЬОВІ АСПЕКТИ
}

Мета роботи - виявлення поетико-інтонаційних особливостей «Gloria» Ф. Пуленка у руслі «неоканону» меси XX ст., а також особливостей відтворення поетики християнської музично-славословної традиції. Методологія роботи спирається на інтонаційну концепцію музики в ракурсі інтонаційностилістичного, етимологічного аналізу, спадкоємного від Б. Асаф'єва та його послідовників, а також на міждисциплінарний та історико-культурологічний підходи. Останні дозволяють виявити духовно-смислову та стильову специфіку «Gloria» Ф. Пуленка в контексті не тільки індивідуального авторського стилю, але й еволюційних шляхів духовного хорового музичного мистецтва Свропи. Наукова новизна статті визначена іiі аналітичним ракурсом, що враховує як жанрові «моделі» католицької меси, починаючи з епохи Середньовіччя, так і особливості відтворення семантико-риторичної специфіки Gloria-славослів'я в однойменному творі Ф.Пуленка. Висновки. Твір Ф. Пуленка за своїми жанрово-інтонаційними показниками апелює до європейської духовно-музичної традиції трактування Gloria як християнського славослів'я, що остаточно склалася у композиторській практиці Нового часу. Сказане $є$ очевидним і в зверненні композитора до кантатного типу побудови Gloria як мікроциклу, і в паралелях з поетикою однойменної кантати А. Вівальді, і в апелюванні до музично-риторичного глоріозного комплексу, і в використанні барочних протиставлень solo та tutti. Paзом 3 тим, «Gloria» Ф. Пуленка виявляє індивідуальність авторського підходу до відтворення поетики християнського славослів'я, що є очевидним в домінантній ролі монодійності, хоральності, бурдонних побудов, уникненні акордовості функціонально-класичного типу та поліфонічних форм (фуга), що в сукупності виявляє типові риси «неоканону» меси XX ст. Ф.Пуленка.

Ключові слова: меса, Gloria, християнське славослів’я, хорова творчість Ф. Пуленка, «Gloria»

(C) Татарнікова А. А., 2019 
Татарникова Анжелика Анатольевна, кандидат педагогических наук, преподаватель кафедры хорового дирижирования Одесской национальной музыкальной академии им. А. В. Неждановой

«Gloria» Ф. Пуленка в контексте традиций христианского славословия: образно-смысловые и жанрово-стилевые аспекты

Цель работы - выявление поэтико-интонационных особенностей «Gloria» Ф. Пуленка в русле «неоканона» мессы XX ст., а также особенностей претворения поэтики христианской музыкально-славословной традиции. Методология работы опирается на интонационную концепцию музыки в ракурсе интонационностилистического, этимологического анализа, унаследованного от Б. Асафьева и его последователей, а также на междисциплинарный и культурологический подходы. Последние позволяют выявить духовно-смысловую и стилевую специфику «Gloria» Ф. Пуленка в контексте не только индивидуального авторского стиля, но и эволюционных путей духовного хорового искусства Европы. Научная новизна статьи определена ее аналитическим ракурсом, учитывающим как жанровые «модели» католической мессы, начиная с эпохи Средневековья, так и особенности претворения семантико-риторической специфики Gloria-славословия в одноименном произведении Ф. Пуленка. Выводы. Произведение Ф. Пуленка по своим жанровоинтонационным показателям апелллирует к европейской духовно-музыкальной традиции трактовки Gloria как христианского славословия, окончательно сложившейся в композиторской практике Нового времени. Сказанное очевидно и в обращении композитора к кантатному типу построения Gloria как микроцикла, и в параллелях с поэтикой одноименной кантаты А. Вивальди, и в апеллировании к музыкально-риторическому глориозному комплексу, и в использовании барочных противопоставлений solo и tutti. Вместе с тем «Gloria» Ф.Пуленка выявляет индивидуальность авторского подхода в претворении поэтики христианского славословия, что очевидно в доминантной роли монодийности, хоральности, бурдонных построений, избегании аккордовости функционально-классического типа и полифонических форм (фуга), что в совокупности выявляет типологические черты «неоканона» мессы XX ст.

Ключевые слова: месса, Gloria, христианское славословие, хоровое творчество Ф. Пуленка, «Gloria» Ф. Пуленка.

Tatarnikova Anzhelika, candidate of pedagogical sciences, teacher of the choral conducting department of the Odessa National Musical Academy. A.V. Nezhdanova

«Gloria» by F. Poulenc in the context of the traditions of Christian glorification: figurative-semantic and genre-style aspects

The purpose of the article is to reveal the poetic-intonational features of F. Poulenc's «Gloria» in the vein of the «neo-canon» of the mass of the 20th century, as well as the peculiarities of translating the poetics of the Christian musical and Slavonic tradition. The methodology of the work is based on the intonational concept of music in the perspective of the intonational-stylistic, etymological analysis inherited from B. Asafiev and his followers, as well as on interdisciplinary and culturological approaches. The latter allows us to identify the spiritual and semantic and style specificity of F. Poulenc's «Gloria» in the context of not only the individual author's style but also the evolutionary paths of the spiritual choral art of Europe. The scientific novelty of the article is determined by its analytical foreshortening, taking into account both the genre «models» of the Catholic Mass, beginning with the Middle Ages, and the peculiarities of the implementation of the semantic-rhetorical specificity of Gloria-theology in the work of F. Poulenc. Conclusions. The work of F. Poulenc in its genre and intonation indicators appeals to the European spiritual and musical tradition of the treatment of Gloria yak Christian praise, finally formed in the composers' practice of modern times. This is also evident in the composer's appeal to the cantata type of the construction of Gloria as a microcycle, and in parallels with the poetics of the same cantata by A. Vivaldi, and in appealing to the musicalrhetorical glorious complex, and in the use of baroque oppositions of solo and tutti. At the same time F. Poulenc's «Gloria» reveals the individuality of the author's approach in translating the poetics of the Christian glorification, which is evident in the dominant role of monody, chorality, burdonian constructions, avoidance of classical-type accordion and polyphonic forms (fugue), which in aggregate reveals typological features «Neo-canon» of the mass of the twentieth century.

Key words: mass, Gloria, Christian praise, choral creativity F. Poulenc, «Gloria» F. Poulenc.

Актуальність. Духовна музика - це найцінніший пласт культури кожного народу і всього людства в цілому. Вона охоплює не тільки богослужбовий спів і наспіви на канонічні тексти; це i композиторські твори, написані для богослужінь або на біблійні сюжети і мотиви, твори, які можуть і не бути пов'язаними з релігійними текстами, але використовують сакральну символіку. На думку В.Ценової, «релігійність - стан, властивість душі людини, що відноситься до його розумових і моральних сил. Тому, коли ми говоримо про релігійність сучасної музики, ми не обмежуємося лише спеціальним шаром духовних жанрів. Йдеться про вічні теми мистецтва, питаннях про сенс буття, про етичну основу музики» [24, 128]. Позначена якість знайшла відкладення і в духовній хоровій творчості Ф. Пуленка, зокрема, в композиції «Gloria», широко затребуваній в сучасній виконавській практиці, що обумовлює актуальність теми представленої роботи.

Аналіз досліджень і публікацій останніх десятиліть виявляє зростаючий інтерес в музикознавстві та культурознавстві до спадщини Ф. Пуленка, зокрема, до його хорових творів, що $\epsilon$ 
очевидним у наукових розвідках О. Кіндюхіної [10], М. Бакун [1], Т. Когут [11], Т. Васіної [2], I. Медведєвої [17] та ін., а також до історичних шляхів розвитку меси, в тому числі іiі жанровостильових метаморфоз у межах духовної музично-історичної традиції та композиторської практики XX ст. $[4 ; 23 ; 6 ; 5 ; 8 ; 14 ; 16$ та ін.]. Однак більшість 3 них орієнтовані на виявлення ознак творчої індивідуальності композитора, в той час як зв'язок його духовно-хорової спадщини, зокрема кантати «Gloria», з духовно-типологічними та семантичними ознаками християнської культової традиції, в тому числі з поетикою славослів'я, поки що залишається поза увагою дослідників.

Мета роботи - виявлення поетико-інтонаційних особливостей «Gloria» Ф. Пуленка у руслі «неоканону» меси XX ст., а також особливостей відтворення поетики християнської музичнославословної традиції. Методологія роботи спирається на інтонаційну концепцію музики в ракурсі інтонаційно-стилістичного, етимологічного аналізу, спадкоємного від Б. Асаф'єва та його послідовників, а також на міждисциплінарний та історико-культурологічний підходи. Останні дозволяють виявити духовно-смислову та стильову специфіку «Gloria» Ф. Пуленка в контексті не тільки індивідуального авторського стилю, але й еволюційних шляхів духовного хорового музичного мистецтва Європи. Наукова новизна статті визначена іiі аналітичним ракурсом, що враховує як жанрові «моделі» католицької меси, починаючи з епохи Середньовіччя, так і особливості відтворення семантико-риторичної специфіки Gloria-славослів’я в однойменному творі Ф. Пуленка.

Виклад основного матеріалу. «Gloria in excelsis Deo»- «Слава в вишніх Богу». Цей текст «ангельського славослів'я» (Лк. 2: 14) здавна був широко відомий в християнській богослужбовій практиці як Сходу, так і Заходу. У першому випадку він найчастіше асоціюється 3 Великим славослів'ям, в той час як у другому виступає складовою частиною Ординарія римо-католицької меси («Gloria»). Відповідно до думки істориків даного жанру, «поетична гідність цього гімну, що виконується безпосередньо після «Господи, помилуй», зумовила його першорядне значення в богослужбовій католицькій традиції» $[22,134]$. Розвиваючи цю думку, Ю. Холопов в своєму нарисі, присвяченому історії меси, зазначає наступне: «Символічне значення глорії - духовна радість через народження Христа, який принесе себе в жертву на вівтарі для порятунку людей. Якщо Кіріє - це переосмислений найдавніший (ще дохристиянський) вигук, то глорія - вже чисто християнський спів». Текст «Слави в вишніх Богу» «...відповідає одному з етапів символічної фабули меси - явищу Спасителя в світ, до громади, до кожної людини» [23, 45].

Відзначимо також, що значимість даного тексту в християнській богослужбовій традиції визначається не тільки іiі новозавітними витоками, а й ключовою роллю образу Божої Слави в християнстві в цілому. В даному випадку він може розглядатися і на рівні богословської категорії, $\mathrm{i}$ на рівні духовно-морального начала, що єднає Божественний і людський світи. Виявляючи специфіку даного взаємозв'язку, блаженний Феодоріт говорить, що «“Господь Бог не має потреби у вихваляючих", однак благоговіння і захоплення розумних творінь Божих величчю Його справ не може не виражатися в підношенні до Бога серцевої хвали і подяки». Розмірковуючи далі про сутність i значимість Божої Слави в людському духовному бутті, протоієрей Ліверій (Воронов) вказує, що «...прославляння Бога життям, справами становить головне призначення людини як причасника любові Божої» [15].

Ємність і всеосяжний характер даного поняття в християнському богослов'ї визначає множинність його значень. Під «Славою Божою» мається на увазі, перш за все, сам Бог або «форма повної присутності Божества» [21]. Саме в цьому значенні використовує дане поняття апостол Павло, коли говорить: «І ми бачили славу Його, як Єдинородного від Отця» (Ін. 1: 14). Для Іоанна Богослова істотним в цьому випадку виступає той факт, що Слава Господня є видимою, і їі можна порівняти 3 випромінюванням сонця і місяця, але перевершує їх (Одкр. 21: 23). Характерно, що етимологія латинського і італійського слова Gloria пов'язана саме з «сяйвом» [див. більш детально про це: 3].

Такий смисловий аспект виявляється співвіднесеним i 3 другим значенням «Слави Господньої», орієнтованим на втілення Божественної абсолютної величі [20], що виявляється в творіннях Бога. «Вона виявляється в Богоявленнях. Тому в Біблії “слава" часто означає самого Бога в прояві Його могутності і в сяйві святості: “І хмара закрила скинію зібрання, і слава Господня наповнила скинію" (Вих. 40: 34)» [7].

Відзначимо також, що позначена якість стане предметом музично-риторичного втілення і в типології Gloria як на рівні складової літургійного циклу, так і рівні самостійного композиційного цілого (А. Вівальді, Ф. Пуленк, К. Сен-Санс). При цьому образ «Божественної величі» пов’язаний 3 просторово-динамічною, «вселенською» якістю його подання, орієнтованою на яскраву динаміку, туттійність, широкий звуковий діапазон тощо. 
Нарешті, ще одне смислове значення поняття «Слави Божої» пов'язане 3 «відображенням Божої величі в справах і об'єктах Його Творіння і Промислу» [20]. «Пізнання Божественної слави можливо як через споглядання створеного Богом світу, так і через дії Божественної благодаті. Споглядаючи світ, людина відчуває нескінченну велич Творця, зводить свій розум до Першопричини світобудови, яка перевершує все, що існує <..> Внутрішнє споглядання слави Божої веде людину до уподібнення своєму Творцеві, до набуття Царства Божого в душі, до духовного преображення...» [20]. Подібне розуміння перетворюючої сутності «Слави Господньої» 6 показовим і для протестантизму. За свідченням Д. Т. Мюллера, «...в лютеранській теології Слава Господня означає стан блаженства, в який будуть введені праведники після Другого Пришестя і воскресіння мертвих» $[18,754-755]$.

Таким чином, образ Божественної слави, славослів'я у всій множинності його тлумачення, що знаменує духовний зв'язок Бога і людини, а також один 3 найважливіших шляхів духовного перетворення останнього, виступає в якості суттєвої категорії християнського світосприйняття i християнської духовної свідомості, що знаходить також відкладення не тільки в богослужбовоспівочій практиці, але і в дотичній до неї духовній музично-історичній традиції. Сказане обумовлює не тільки істотну роль Gloria як розділу меси, але і можливість виділення іiї в якості самостійного твору (на рівні кантати) в творчості А. Вівальді, К. Сен-Санса, Ф. Пуленка.

Зміна місця розташування Gloria в ході еволюції християнського богослужіння (спочатку утреня, пізніше меса-літургія в католицькій традиції) фіксує активну взаємодію східнохристиянської та західної традицій, показову ще для епохи «неподіленої Церкви». Особлива значимість Gloria в літургійному циклі, визначена ii високим духовним змістом, обумовлює не тільки семантикотипологічні якості даного розділу богослужіння, його домінуючу роль як складової missa brevis, але й в кінцевому підсумку іiї існування у вигляді самостійної композиції кантатного типу в музиці XVIII$\mathrm{XX}$ ст.

Історико-еволюційні шляхи розвитку меси i Gloria як її складової так чи інакше фіксували позначені смислові якості даного розділу у відповідному стильовому i музично-риторичному відбитті. Так епоха Середньовіччя характеризується пануванням монодії та виконавської диференціації, відповідно до якої пріоритетна роль в оголошенні-співі «ангельського славослів'я» спочатку віддавалася єпископу і духовенству.

Меса епохи Ренесансу являє собою масштабну циклічну композицію 3 розвиненим багатоголоссям, яке передбачає професійне хорове виконавство, зі значною роллю авторського (композиторського) начала, не виключає введення в якості Cantus firmus мелодійного матеріалу негрегоріанского походження, що нерідко символізує гармонію-єднання Божественного і людського начал, показові для ренесансної епохи.

Meca XVII-XVIII ст., зберігаючи статус високого серйозного жанру, зверненого до духовної архетипової тематики, характеризується активною взаємодією з іншими типологіями (в тому числі оперою, пізніше - сонатно-симфонічним циклом), здійснюваною в стильових параметрах бароко i класицизму і властивими їм музично-риторичними «формулами».

Сказане $є$ співвідносним і з типологічними якостями Gloria, яка у творчості авторів названого періоду набуває рис кантатного мікроциклу (Й. С. Бах, В. А. Моцарт, Л. ван Бетховен та ін.) в рамках меси або самостійного твору (А. Вівальді). При цьому музична риторика Gloria («радість», славослів'я) виявляється співвідносною $з$ семантикою тональної сфери C-dur, D-dur, B-dur, 3 пріоритетною роллю тембральності мідних духових інструментів (труби) і властивою їм квартоквінтовою інтонаційністю, яскравою динамікою, туттійністю, домінуванням риторичних фігур типу anabasis, fuga, що в сукупності визначає «вселенський» характер даного розділу як славослів'я «ангельського воїнства» і причетного до нього людства.

Одним із символів подібного єднання в Gloria розглянутого періоду виступає підсумкова фуга, що вінчає композицію даного розділу і співвідноситься за семантичними параметрами з «ідеєю єдності і гармонії світобудови як концептуальної домінанти» $[12,9]$. Епоха романтизму демонструє подальші еволюційні шляхи духовно-хорової жанрової сфери, в тому числі i Gloria в складі меси. В даний період для неї показовим $\epsilon$, з одного боку, посилення національного чинника, який вступає у взаємодію з риторикою духовного жанру (Ф. Шуберт, Ф. Ліст), 3 іншого - зближення меси 3 типологією симфонічного жанру при одночасному відродженні ренесансно-барокової духовномузичної традиції (А. Брукнер).

Окреслені процеси показові і для французької музичної культури першої половини ХХ ст., яка вирізнялася множинністю стильових напрямків і шукань, що багато в чому було обумовлено не тільки статусом Парижа як центру європейської культури і музики, а й традиціями його музично- 
освітніх установ (консерваторія, Schola Cantorum, школа Нідермейера та ін.) [13]. Строкатість неформальних об'єднань французьких музикантів, тим не менш, з усією очевидністю демонструє дві характерні тенденції, орієнтовані, 3 одного боку, на пошук нового, 3 іншого - на захист консервативно-охоронних принципів розвитку музичного мистецтва, що апелюють до вивчення старовинних музично-історичних традицій, жанрових систем, пов'язаних, перш за все зі сферою духовного музичного мистецтва і близького йому. Подібного роду перетин традицій і новацій багато в чому визначив «неоканон» меси XX ст., орієнтований на «суміщення історичних пластів, стильових та культурних парадигм» $[9,343]$, актуальне і для хорової творчості Ф. Пуленка.

Узагальнюючи матеріали бібліографії, присвяченій спадщині композитора, відзначимо, що аналіз духовно-християнської складової творчої особистості Ф. Пуленка, iї ролі в його біографії i особливостей відтворення в хоровій творчості даного автора лише недавно стали предметом музично-історичних досліджень, що багато в чому обумовлено як соціально-історичною специфікою його епохи і їі духовними пошуками, так і обставинами особистого життя Ф. Пуленка. За словами Анрі Еля, він був «першим релігійним музикантом свого часу». «Його творчий шлях - це постійне балансування між духовним і світським, “небесним” і “земним”» $[11,4]$.

Глибина його віри багато в чому була пов’язана з впливом батька і давніми спадковими релігійними традиціями його сім'ї, про що неодноразово згадував Ф. Пуленк і що було очевидним i для найближчого оточення композитора. Так С. Одель відзначав: «Віра горіла в ньому рівно, як спокійна впевненість, як найвище станище, подароване провидінням» $[11,25]$. Додамо також, що «спадкова релігійність» Ф. Пуленка в 1930-і роки також істотно доповнювалася іншими драматичними обставинами його біографії - смертю батьків, загибеллю близького друга П'єраОктава Ферро. Особисті трагедії поглиблювалися тривожною атмосферою 30-х років XX ст.

Зазначена духовна складова творчості Ф. Пуленка та його епохи найповніше відкладення отримала саме в його духовних хорових композиціях і чітко позначила, починаючи 31936 р., «релігійний зворот» його творчої діяльності. Перші хори Ф. Пуленка з'явилися ще в 1920-і роки, проте тільки з середини 1930-х рр. твори для хору, пов'язані з духовною тематикою стають невід'ємною частиною його спадщини.

Сказане повною мірою є співвідносним і з Літаніями Чорної Богоматері (1936), зверненої до святині Рокамадура, куди Ф. Пуленк неодноразово здійснював паломництва, і з Месою G-dur для змішаного хору a cappella (1937), i з особливим інтересом до жанру мотета (чотири покаянних мотета (1938-1939), чотири різдвяних мотета (1951-1952) для змішаного хору а cappella). Поетика духовної хорової спадщини Ф. Пуленка також представлена і в Чотирьох маленьких молитвах святому Франциску Ассизькому (1948) для чоловічого хору a cappella, i в композиції Ave Verum Corpus для жіночого тріо (1952), і в Лауді Святому Антонію Падуанському (1959) для чоловічого хору а cappella. Вінцем хорової творчості Ф. Пуленка по праву вважається кантата «Stabat Mater» (1951) i «Gloria» (1959), що в повній мірі узагальнили і відобразили стильові якості хорового письма композитора, які так чи інакше тяжіли до «стилістичної багатомовності» при домінуючої ролі, тим не менш, стародавньої духовно-співочої традиції.

Сказане багато в чому визначило і жанрово-стильову специфіку кантати «Gloria». Твір Ф. Пуленка, з одного боку, за багатьма своїми жанрово-інтонаційними показниками апелює до європейської духовно-музичної традиції трактування Gloria як християнського славослів'я, що склалося в композиторській практиці Нового часу. Сказане проявляється і в зверненні композитора до кантатного типу побудови Gloria як мікроциклу (в даному випадку шестичасного), та в очевидних паралелях 3 поетикою «Gloria» А. Вівальді [див.: 11, 148], і в апеляції до музично-риторичного глоріозного комплексу (істотна роль мідної духової групи, типології маршу, танцю, яскравої динаміки, фактурної масштабності, семантики певного кола тональностей тощо). Співвіднесеність 3 бароковою традицією також очевидна і в використанні принципу протиставлення солюючих груп $\mathrm{i}$ tutti.

3 іншого боку, «Gloria» Ф. Пуленка в своїх інтонаційно-стилістичних і фактурних показниках суттєво відрізняється від аналогічних творів авторів XVII-XIX ст., оскільки більшою мірою звернена до творчого відтворення (з позицій автора першої половини XX ст.) середньовічної та ренесансної традиції. Сказане проявляється в домінуючій ролі монодійного начала i хоральності в іiі ранньосередньовічному розумінні. Акордовість функціонально-класичного типу як така представлена мінімально, поступаючись місцем багатоголоссю гетерофонного і бурдонного (ісонового) типів. Протягом усього твору автор принципово уникає традиційних імітаційно-поліфонічних побудов (фуга), в тому числі і у фінальній його частині, що раніше становило один з обов'язкових атрибутів поетики Gloria. 
Фінал своєї композиції Ф. Пуленк вирішує з позицій акцентування виразних можливостей «тихої» кульмінації та іiі перетворюючого ефекту в рамках духовно-смислової специфіки використовуваного богослужбового тексту. На відміну від своїх попередників, Ф. Пуленк не використовує в своєму циклі чисто сольних аріозних номерів, але віддає перевагу респонсорним принципам співвідношення соло сопрано і хору, що зближує твір з церковно-літургійною практикою.

Специфіка музичного матеріалу аналізованого твору полягає в тому, що, поряд зі стилізованим відтворенням елементів грегоріаніки і псалмодії, автор віддає перевагу мікротематизму, коротким інтонаційним ритмоформулам (1-2 такти) як засобу «озвучування» духовно-смислових деталей тексту. Їх виразність істотно доповнюється використанням прийомів музичної риторики. Комбінування тематичних складових в оркестровій та хоровій партитурах Gloria Ф. Пуленка багато в чому визначає властиву для даного твору жанрово-стильову і ладово-інтонаційну «мозаїчність» в руслі «неоканонічних» тенденцій духовної музики XX ст.

Висновки. Твір Ф. Пуленка за своїми жанрово-інтонаційними показниками апелює до європейської духовно-музичної традиції трактування Gloria як християнського славослів'я, що остаточно склалася у композиторській практиці Нового часу. Сказане є очевидним і в зверненні композитора до кантатного типу побудови Gloria як мікроциклу, i в паралелях 3 поетикою однойменної кантати А. Вівальді, і в апелюванні до музично-риторичного глоріозного комплексу, і в використанні барочних протиставлень solo та tutti. Разом 3 тим «Gloria» Ф. Пуленка виявляє індивідуальність авторського підходу до відтворення поетики християнського славослів'я, що $\epsilon$ очевидним в домінантній ролі монодійності, хоральності, бурдонних побудов, уникненні акордовості функціонально-класичного типу та поліфонічних форм (фуга), що в сукупності виявляє типові риси «неоканону» меси XX ст.

\section{Лimepamyра}

1. Бакун М. И. Трактовка жанров духовной музыки в творчестве Франсиса Пуленка. Автореф. дисс... канд. искусствоведения : 17.00.02 - Музыкальное искусство. СПб.: Санкт-Петербургская государственная консерватория (академия) им. Н. А. Римского-Корсакова, 2013. 23 с.

2. Васіна Т. «Gloria» Ф. Пуленка: проблема жанрово-інтонаційних витоків // Київське музикознавство. К., 2010. Вип. 35. С. 212-219.

3. Глория. URL: https://ru.wiktionary.org/wiki/Глория (дата звернення: 04.01. 2017 р.)

4. Григорианский хорал: сб. науч. тр. М.: МГК им. П. И. Чайковского, 1997. 221 с.

5. Гулецки И. Manus misterialis: символика формы ренессансной мессы // Opera musicologica. 2009. № 1. C. $32-81$.

6. Евдокимова Ю., Симакова Н. Музыка эпохи Возрождения: Cantus prius factus и работа с ним. М.: Музыка, 1982. 252 с.

7. Иов (Гумеров). Что такое «слава» в христианском понимании? URL : pravoslavie.ru/7140.html (дата звернення: 15.08. 2017 р.)

8. Кальченко Е. В. Месса в музыке XX века: к проблеме неоканона. Дисс... канд. искусствоведения : 17.00.02 - Музыкальное искусство. М.: МГК им. П. И. Чайковского, 2016. 281 с.

9. Катунян М.И. Плач Иеремии: сакральное слово и неоканонический стиль Владимира Мартынова // Слово и музыка: Научные труды МГК им. П.И. Чайковского. Сб. 36. М., 2002. С. 341-351.

10. Киндюхина Е. А. Музыкальный театр Франсиса Пуленка. Автореф. дисс... канд. искусствоведения : 17.00.02 - Музыкальное искусство. М.: РАМ им. Гнесиных, 2011. 27 с.

11. Когут Т. В. Духовні твори Франсіса Пуленка: особливості прочитання сакральних текстів. Дис... канд.. мистецтвознавства : 17.00.03 - Музичне мистецтво. Київ: НМАУ ім. П. І. Чайковського, 2017. 219 с.

12. Коробейников С. С. Фуга XIX века в стилевом контексте музыкального романтизма: На примере произведений Ф. Мендельсона и М. Регера. Дисс... канд. искусствоведения : 17.00.02 - Музыкальное искусство. Новосибирск, 2001. 161 с.

13. Кривицкая Е. Д. Музыка Франции: век двадцатый. Эстетика, стиль, жанр. М.-СПб.: Центр ГИ, 2012. $336 \mathrm{c}$.

14. Левик Б. В. Gloria // Музыкальная энциклопедия: в 6-ти томах. М.: Советская энциклопедия, 1973. Т. 1. Стлб. 1016.

15. Ливерий (Воронов), протоиерей. Догматическое богословие. URL : https://azbuka.ru/otechnik/LiverijVoronov/ (дата звернення: 01.12.2017 р.)

16. Люстиже Ж.-М. Месса / Пер. с фр. П. Сахарова. М.: Истина и жизнь, 2001. 109 с.

17. Медведева И. Франсис Пуленк. М.: Советский композитор, 1969. 238 с.

18. Мюллер Д. Т. Христианская догматика. Минск: Лютеранское наследие, 1998. 766 с.

19. Пуленк Ф. Дневники моих песен. Я и мои друзья. М.: Композитор, 2005. 160 с.

20. Слава Божия. URL : https://azbuka.ru/slava-bozhiya (дата звернення: 10.12. 2016 p.)

21. Слава Господня. URL : https://ru.wikipedia.org/wiki/Слава_Господня (дата звернення 25.11. 2017 p.) 
22. Фиденко Ю. Л. Музыкально-литургическая практика католических приходов азиатской части России на рубеже XX-XXI веков. - Дисс. ...доктора искусствоведения : 17.00.02 - Музыкальное искусство. Новосибирск: Новосибирская государственная консерватория имени М. И. Глинки, 2016. 436 с. C. $38-65$.

23. Холопов Ю. Н. Месса // Григорианский хорал: сб. науч. тр. М.: МГК им. П. И. Чайковского, 1997.

24. Ценова В. С. Новая религиозность русской музыки и духовные сочинения Эдисона Денисова // Московский форум. Музыка XX века: Научные труды МГК им. П. И. Чайковского. М.: МГК им. П.И.Чайковского, 1999. Сб. 25. С. 128-141.

\section{References}

1. Bakun, M.I. (2013). Interpretation of genres of sacred music in the work of Francis Poulenc. Extended abstract of candidate's thesis. St. Petersburg [in Russian].

2. Vasina, T. (2010). «Gloria» by F. Poulenc: problem of genre-intonation origins. Kyyivs $\square$ ke muzykoznavstvo. 35, 212-219 [in Ukrainian].

3. Gloria (2017). Retrieved from https://ru.wiktionary.org/wiki/Глория

4. Gregorian chorale (1997). Moscow : MGK im. P. I. Chaykovskogo [in Russian].

5. Guletski, I. (2009). Manus misterialis: symbolism of the form of the Renaissance Mass. Opera musicologica. 1, 32-81 [in Russian].

6. Evdokimova Yu., Simakova N. (1982). Music of the Renaissance: Cantus prius factus and work with him. Moscow : Muzyika in Russian].

7. Iov (Gumerov) (2017). What is «glory» in the Christian sense? Retrieved from pravoslavie.ru/7140.html

8. Kalchenko, E. V. (2016). Mass in the music of the twentieth century: the problem of neo-canon. Candidate's thesis. Moscow : MGK im. P. I. Chaykovskogo [in Russian].

9. Katunyan, M.I. (2002). The cry of Jeremiah: the sacred word and the neo-canonical style of Vladimir Martynov. Slovo i muzyika: Nauchnyie trudyi MGK im. P.I. Chaykovskogo. 36, 341-351 [in Russian].

10. Kindyuhina, E. A. (2011). Musical Theater of Francis Poulenc. Extended abstract of candidate's thesis. Moscow : RAM im. Gnesinyih [in Russian].

11. Kogut, T. V. (2017). Spiritual works of Francis Poulenc: features of reading sacred texts. Candidate's thesis. Kiev: NMAU im. P. I. Chaykovskogo [in Ukrainian].

12. Korobeynikov, S. S. (2001). Fugue of the XIX century in the style context of musical romanticism: On the example of the works of F. Mendelssohn and M. Reger. Candidate's thesis. Novosibirsk: Novosibirskaya gosudarstvennaya konservatoriya imeni M. I. Glinki [in Russian].

13. Krivitskaya, E. D. (2012). French music: the twentieth century. Aesthetics, style, genre. Moscow - St. Petersburg: Tsentr GI [in Russian].

14. Levik, B. V. (1973). Gloria. Muzyikalnaya entsiklopediya. 1, 1016 [in Russian].

15. Liveriy (Voronov), protoierey (2017). Dogmatic theology. Retrieved from https://azbuka.ru/otechnik/Liverij-Voronov/

16. Lyustizhe, Zh.-M. (2001). The mass. Moscow : Istina i zhizn [in Russian].

17. Medvedeva, I. (1969). Francis Poulenc. Moscow : Sovetskiy kompozitor [in Russian].

18. Myuller, D. T. (1998). Christian dogmatics. Minsk: Lyuteranskoe nasledie [in Belarus].

19. Poulenk, F. (2005). Diaries of my songs. Me and my friends. Moscow: Kompozitor [in Russian].

20. The Glory of God (2016). Retrieved from https://azbuka.ru/slava-bozhiya

21. Glory of the Lord (2017). Retrieved from https://ru.wikipedia.org/wiki/Слава_Господня

22. Fidenko, Yu. L. (2016). The musical and liturgical practice of the Catholic parishes of the Asian part of Russia at the turn of the 20th and 21st centuries. Dissertation of the doctor of art criticism. Novosibirsk: Novosibirskaya gosudarstvennaya konservatoriya imeni M. I. Glinki [in Russian].

23. Holopov, Yu. N. (1997). The mass. Moscow : MGK im. P. I. Chaykovskogo [in Russian].

24. Tsenova, V. S. (1999). The new religiosity of Russian music and the spiritual writings of Edison Denisov. Moskovskiy forum. Muzyika XX veka: Nauchnyie trudyi MGK im. P. I. Chaykovskogo. 25, 128-141 [in Russian].

Стаття надійшла до редакциї 11.02.2019 p. 